\title{
KARAKTERISTIK PERTUMBUHAN Leucaena leucocephala cv. Tarramba TERCEKAM ALUMUNIUM PADA SISTEM KULTUR JARINGAN
}

\author{
Prihantoro I, Manpaki SJ, Karti PDMH \\ Depertemen IImu Nutrisi dan Teknologi Pakan, Fakultas Peternakan, Institut Pertanian Bogor. \\ Email: iprihantoro@yahoo.com
}

\begin{abstract}
ABSTRAK
Leucaena leucocephala merupakan salah satu sumber daya pakan dengan kandungan protein tinggi. Tanaman L. leucocephala cv. Tarramba memiliki produktivitas yang tinggi, sangat tahan terhadap kekeringan, dan tahan terhadap hama kutu loncat. Tujuan penelitian adalah untuk mengetahui karakteristik pertumbuhan L. leucocephala cv. Tarramba tercekam alumunium pada media kultur jaringan. Penelitian dirancang menggunakan rancangan acak lengkap (RAL) dengan tiga level $\mathrm{Al}^{+}$(o ppm; $100 \mathrm{ppm}$, dan $200 \mathrm{ppm}$ ) dengan masing-masing perlakuan terdiri atas 10 ulangan. Parameter yang diamati adalah pertambahan tinggi kanopi tanaman, kerontokan daun majemuk, dan perubahan $\mathrm{pH}$ media. Hasil penelitian menunjukkan bahwa pertambahan tinggi kanopi tanaman menurun seiring meningkatnya level $\mathrm{Al}^{3+}$ dan jumlah kerontokan daun majemuk meningkat seiring meningkatnya level $\mathrm{Al}^{3+}$. Penambahan $\mathrm{Al}^{3+}$ cenderung meningkatkan nilai akhir $\mathrm{pH}$ media dibandingkan nilai $\mathrm{pH}$ diawal perlakuan.
\end{abstract}

Kata kunci: Leucaena leucocephala cv. tarramba, alumunium, kultur jaringan, pH media

\section{PENDAHULUAN}

Usaha peternakan nasional didominasi oleh peternakan rakyat $>95 \%$ dengan pola manegemen konvensional. Pakan hijauan merupakan pakan utama dalam budaya peternakan rakyat dengan penggunahan hingga 100\%. Kualitas pakan hijauan di Indonesia relatif rendah protein dan tinggi serat kasar. Hijauan pakan ternak merupakan sumber pakan utama bagi ternak ruminansia, khususnya pada peternakan skala rakyat. Secara umum, kualitas dan produktivitas hijauan pakan di daerah tropis masih relatif rendah. Hijauan pakan dibedakan menjadi dua famili besar yaitu graminae dan leguminosae. Leguminosa merupakan jenis hijauan pakan sumber protein. Salah satu jenis leguminosa yang sudah dikenal baik oleh peternak adalah lamtoro (Leucaena leucocephala). Tanaman lamtoro memiliki kandungan protein kasar yang tinggi yakni sebesar 23.7\%-34\% dengan palatabilitas yang tinggi (Yumiarty dan Suradi, 2010).

Lamtoro mampu beradaptasi dengan baik di daerah tropis dan mampu beradaptasi pada tanah dengan kemasaman sedang antara $\mathrm{pH}$ 5,5 - 6,5 dengan curah hujan tahunan di atas $760 \mathrm{~mm}$ (Hoult dan Briant, 1974). Salah satu varietas lamtoro yang sudah berkembang baik di Indonesia adalah varietas Tarramba. Penelitian Yurmiaty dan Suradi (2010) lamtoro varietas Tarramba (L. leucocephala $c v$. Tarramba) memiliki keunggulan tahan terhadap hama kutu loncat dan tahan pada kondisi kering. Keunggulan lain dari lamtoro kultivar Tarramba adalah tinggi kandungan protein (15-18\%), vitamin, dan mineral. Kultivar ini memiliki kemampuan produktivitas lebih tinggi (11 ton $\mathrm{BK} \mathrm{ha}^{-1}$ ) dibanding kultivar lokal $\left(8,1\right.$ ton $\left.\mathrm{BK}^{-1}\right)$.

Indonesia memiliki potensi lahan dengan sifat tanah kering masam yang luas. Penelitian Hidayat dan Mulyani (2005) potensi luas lahan kering masam di Indonesia sebesar 99,6 juta hektar yang tersebar di Kalimantan, Sumatera, Maluku, Papua, Sulawesi, Jawa dan Nusa Tenggara. Kemasaman tanah dapat disebabkan karena kandungan aluminium tanah yang cukup tinggi. Logam aluminium bisa menjadi racun bagi tanaman yang tumbuh. Penelitian Sanchez (1992) pengelompokkan kemasaman tanah terdiri dari sangat masam $\mathrm{pH}<4,5$, masam $\mathrm{pH} 4,5-5,5$, agak masam $\mathrm{pH}$ 5,6-6,5, dan netral pH 6,6-7,5. Penelitian Hidayat dan Mulyani (2005) pada tanah masam serta miskin unsur hara, mengakibatkan pertumbuhan tanaman terganggu sehingga produktivitas tanaman menurun secara signifikan. Black (1967) menegaskan bahwa pertumbuhan tanaman yang tidak subur pada tanah disebabkan oleh kejenuhan aluminium, kejenuhan aluminium akan mengakibatkan tanaman rentan terhadap kekeringan, terganggunya penyerapan zat hara media, sehingga pertumbuhan dan perkembangan terhambat. Hingga saat ini, kajian tingkat toleransi L. leucocephala $\mathrm{cv}$. tarramba terhadap media tanah masam masih relatif terbatas.

Pemanfaatan teknologi kultur jaringan memungkinan untuk melakukan kajian secara cepat dan akurat. Lebih lanjut, teknologi kultur jaringan pada budidaya lamtoro memungkinkan untuk memaksimalkan perbanyakan eksplan dalam kondisi steril. Teknologi ini juga efektif dalam bibit pakan 
hijauan yang unggul, seragam, banyak, dan dalam waktu yang cepat. Menggunakan teknik ini akan memberikan peluang untuk mengetahui mekanisme dasar toleransi tanaman terhadap cekaman aluminium secara morfologi dan fisiologis. Tujuan penelitian adalah untuk mengetahui karakteristik pertumbuhan L. leucocephala $c v$. Tarramba tercekam alumunium pada media kultur jaringan.

\section{METODE}

\section{Bahan}

Bahan yang digunakan dalam penelitian adalah biji lamtoro (L. leucocephala $c v$. Tarramba) yang diperoleh dari kebun koleksi Laboratorium Lapang Ilmu dan Teknologi Tumbuhan Pakan dan Pastura, Fakultas Peternakan Institut Pertanian Bogor. Bahan sterilisasi berupa alkohol 70\%, alcohol 96\%, sabun cuci, clorox $10 \%$ sampai $20 \%$, aquades, zat pengatur tumbuh kinetin (6-furfuryl amino purine) dan BAP (6-benzyl amino purine), media MS (Murashige Skoog) basal, $\mathrm{AlCl}_{3}$.

\section{Alat}

Peralatan yang digunakan dalam penelitian ini meliputi laminar air flow, botol kultur jaringan kapasistas kecil, botol kultur jaringan kapasitas sedang, jangka sorong, magnetic stirrer, leaf colour chart, $\mathrm{pH}$ meter, dan autoclave.

\section{Lokasi dan Waktu}

Penelitian dilakukan di Laboratorium Kultur Jaringan Tanaman Pakan Bagian Ilmu dan Teknologi Tumbuhan Pakan dan Pastura, Fakultas Peternakan, Institut Pertanian Bogor. Penelitian terdiri dari 2 tahap yakni (1) subkultur eksplan murni dan (2) multiplikasi tanaman lamtoro pada media asam dengan level pemberian aluminium.

\section{Prosedur}

Persiapan Eksplan

Biji lamtoro yang akan disemai dicuci menggunakan sabun sampai bersih untuk kemudian disterilisasi menggunakan Clorox 20\% selama 7 menit, kemudian Clorox 15\% selama 7 menit, dan direndam kembali dalam Clorox 10\% selama 7 menit. Setelah dilakukan perendaman, biji dibilas dalam aquades selama 5 menit. Biji steril ditanam dalam botol berisi media MS o sebanyak $20 \mathrm{ml}$. Setelah biji berkecambah dan tumbuh menjadi tanaman lengkap dijadikan sebagai sumber eksplan. Eksplan yang digunakan adalah bagian batang lamtoro yang telah memiliki buku sebagai tempat tumbuhnya tunas (meristem aksilar).

\section{Pembuatan Media}

Penelitian menggunakan 3 jenis media yang terdiri atas: (1) media Murashige Skoog (MS) o (basal) padat sebagai media perkecambahan, (2) Media Murashige Skoog (MS) dengan penambahan Kinetin dan BAP masing-masing $1 \mathrm{mg}$ liter $^{-1}$ sebagai media induksi tunas, dan (3) Media Murashige Skoog (MS) dengan penambahan Kinetin dan BAP masingmasing $1 \mathrm{mg}$ liter ${ }^{-1}$ dan penambahan $\mathrm{AlCl}_{3}$ sebagai media perlakuan. Penambahan $\mathrm{AlCl}_{3}$ berdasarkan rentang perlakuan meliputi tanpa $\mathrm{Al}^{3+}$ (kontrol), $100 \mathrm{ppm} \mathrm{Al}^{3+}, 200 \mathrm{ppm} \mathrm{Al}^{3+}$. Pembuatan media perlakuan (padat) dengan menyediakan gelas beker yang telah mengandung komposisi MS, dimulai dengan pemanasan dengan menggunakan kompor gas dan setelah mendidih dimasukkan di dalam botol kultur sebanyak $20 \mathrm{ml}$ setiap botol, beberapa menit kemudian, ditutup dengan aluminium foil diikuti dengan sterilisasi dalam autoklaf selama 30 menit dengan suhu $122^{\circ} \mathrm{C}$ pada tekanan 17.5 psi. Media selanjutnya disimpan dalam ruang kultur jaringan dan diamati selama 1 minggu untuk mencegah penggunaan media yang terkontaminasi.

\section{Tahap 1: Induksi Tunas}

Media utama yang digunakan dalam induksi tunas tanaman leguminosa adalah media MS ditambah zat pengatur tumbuh (ZPT) Kinetin (6-furfuryl amino purine) dan BAP (6-benzyl amino purine) masing-masing $1 \mathrm{mg} \mathrm{liter}^{-1}$. Eksplan yang digunakan adalah bagian batang yang memiliki cabang tempat tumbuhnya tunas yang dipindahkan ke dalam media dengan teknik subkultur di dalam laminar airflow. Setiap botol berisi media sebanyak $20 \mathrm{ml}$ yang ditanami ekslpan tanpa perlakuan. Induksi tunas diamati selama enam minggu. Eksplan yang tumbuh ditunggu hingga menjadi tunas dan tanaman lengkap. Lamtoro yang tumbuh dengan baik dipilih untuk kemudian dilakukan multiplikasi dan dilanjutkan dengan pengujian perlakuan asam.

Tahap 2: Multiplikasi Eksplan pada Media Perlakuan Asam

Media utama yang digunakan dalam induksi jaringan meristematik sehingga menjadi tanaman utuh lamtoro adalah media MS ditambah zat pengatur tumbuh (ZPT) Kinetin (6- furfuryl amino purine) dan BAP (6-benzyl amino purine) masing-masing $1 \mathrm{mg}$ liter ${ }^{-1}$ dengan perlakuan asam $\mathrm{AlCl}_{3}$ masingmasing adalah o ppm $\mathrm{Al}^{3+}, 100 \mathrm{ppm} \mathrm{Al}^{3+}, 200 \mathrm{ppm}$ $\mathrm{Al}^{3+}$. Eksplan yang digunakan adalah bagian batang tanaman yang memiliki cabang tempat tumbuhnya tunas yang dipindahkan ke dalam media dengan teknik subkultur di dalam laminar airflow. Setiap botol berisi media sebanyak $20 \mathrm{ml}$ yang ditanami 2 
ekslpan sesuai dengan perlakuan masing- masing. Pertumbuhan tanaman lamtoro diamati selama 4 minggu. Eksplan yang tumbuh baik mengindikasikan penggunaan media tumbuh yang baik dan taraf kemasaman media yang optimum.

Parameter yang diukur dalam penelitian meliputi: (1) pertambahan tinggi kanopi tanaman, (2) kerontokan daun majemuk, dan (3) perubahan $\mathrm{pH}$ media. Penelitian dirancang menggunakan rancangan acak lengkap (RAL) dengan tiga level $\mathrm{Al}^{3+}$ (o ppm; $100 \mathrm{ppm}$, dan $200 \mathrm{ppm}$ ) dengan masing-masing perlakuan terdiri atas 10 ulangan.

\section{HASIL DAN PEMBAHASAN}

\section{Tinggi kanopi tanaman lamtoro (L. leucoceph-} ala cv. Tarramba) yang tercekam $\mathrm{Al}^{3+}$

Tinggi kanopi merepresentasikan respon morfologi tanaman terhadap perlakuan alumunium yang diberikan. Hasil sidik ragam menunjukkan bahwa peningkatan level $\mathrm{Al}^{3+}$ menurunkan pertambahan jumlah kanopi tanaman secara signifikan $(\mathrm{P}<\mathrm{O}, 05)$. Penurunan pertambahan kanopi dimungkinkan akibat gangguan transport hara seiring meningkatnya level $\mathrm{Al}^{3+}$. Wright (1989) menegaskan bahwa aluminium akan menghambat pengangkutan dan penggunaan unsur-unsur esensial seperti $\mathrm{Ca}, \mathrm{Mg}, \mathrm{P}, \mathrm{K}$, dan $\mathrm{Fe}$, hal tersebut dimungkinkan akibat terhambatnya pertumbuhan akar sekunder yang disebabkan pengikatan $\mathrm{Al}^{3+}$ pada varietas-varietas tanaman yang tidak toleran terhadap $\mathrm{Al}^{3+}$.

Tabel 1. Pertambahan tinggi kanopi tanaman (L. leyçocephala $\mathrm{cV}$. Tarramba) berdasarkan level pemberian $\mathrm{Al}^{3}$

\begin{tabular}{|c|c|c|c|}
\hline \multirow{3}{*}{$\begin{array}{c}\text { Umur Tanaman } \\
\text { (minggu) }\end{array}$} & \multicolumn{3}{|c|}{ Level $\mathrm{Al}^{3+}(\mathrm{ppm})^{*}$} \\
\hline & 0 & 100 & 200 \\
\hline & \multicolumn{3}{|c|}{ 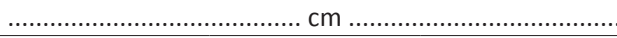 } \\
\hline 1 & $0,20 \pm 0,16$ & $0,25 \pm 0,20$ & $0,17 \pm 0,15$ \\
\hline 2 & $0,48 \pm 0,28 a$ & $0,36 \pm 0,24 a b$ & $0,29 \pm 0,15 b$ \\
\hline 3 & $0,81 \pm 0,40 a$ & $0,44 \pm 0,24 b$ & $0,39 \pm 0,12 b$ \\
\hline 4 & $1,03 \pm 0,36 a$ & $0,49 \pm 0,22 b$ & $0,46 \pm 0,17 b$ \\
\hline
\end{tabular}

*adalah level $\mathrm{Al}^{3+}(0 \mathrm{ppm}=\mathrm{pH} \mathrm{6,5;} 100 \mathrm{ppm}=\mathrm{pH} \mathrm{5,5;} \mathrm{dan} 200 \mathrm{ppm}=\mathrm{pH}$ 4,4) Superskrip berbeda pada baris yang sama menunjukkan beda nyata $(P<0,05)$

\section{Kerontokan daun majemuk tanaman lamtoro} (L. leucocephala cv. Tarramba) tercekam $\mathrm{Al}^{3+}$

Kerontokan daun majemuk adalah jumlah daun majemuk yang rontok terhadap total daun majemuk. Kerontokan daun majemuk memiliki hubungan terBalik dengan pertambahan jumlah daun majemuk. Hal tersebut menjadi indikator bahwa terdapat interaksi negatif yang disebabkan oleh tanaman. Kerontokan daun disebabkan oleh proses adaptasi fisiologis tanaman dan model toleransi tanaman terhadap keracunan mineral tertentu salah satunya aluminium. Persentase kerontokan daun tanaman $(L$. leucocephala cv. Tarramba) disajikan pada Tabel 2.

Tabel 2. Kerontokan daun majemuk tanaman (L. leuçocephala $\mathrm{cv}$. Tarramba) berdasarkan level pemberian $\mathrm{Al}^{3}$

\begin{tabular}{|c|c|c|c|}
\hline \multirow{3}{*}{$\begin{array}{l}\text { Umur Tanaman } \\
\text { (minggu) }\end{array}$} & \multicolumn{3}{|c|}{ Level $\mathrm{Al}^{3+}(\mathrm{ppm})^{*}$} \\
\hline & 0 & 100 & 200 \\
\hline & \multicolumn{3}{|c|}{ 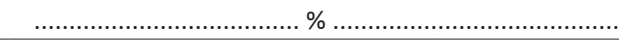 } \\
\hline 1 & $0,00 \pm 0,00$ & $4,76 \pm 10,99$ & $14,32 \pm 19,47$ \\
\hline 2 & $2,67 \pm 5,84$ & $6,81 \pm 11,55$ & $18,33 \pm 17,67$ \\
\hline 3 & $2,67 \pm 5,84$ & $10,85 \pm 15,65$ & $21,55 \pm 18,81$ \\
\hline 4 & $2,67 \pm 5,84$ & $14,52 \pm 19,26$ & $23,97 \pm 17,90$ \\
\hline
\end{tabular}

*adalah level $\mathrm{Al}^{3+}(0 \mathrm{ppm}=\mathrm{pH} 6,5 ; 100 \mathrm{ppm}=\mathrm{pH}$ 5,5; dan $200 \mathrm{ppm}=\mathrm{pH}$ 4,4)

Pola kerontakan daun majemuk cenderung selaras dengan meningkatnya level $\mathrm{Al}^{3+}$ yang diberikan. Meskipun demikian, nilai kerontokan daun majemuk (\%) belum menunjukkan perbedaan yang signifikan, yang lebih disebabkan oleh tingginya nilai simpangan baku dari parameter yang diukur. Kecenderungan peningkatan kerontokan menunjukkan adanya indikasi mekanisme fisiologis dari tanaman untuk menggugurkan daun yang disebabkan keracunan $\mathrm{Al}^{3+}$. Penelitian Marschner (1986) pada media yang jenuh aluminium akan menggeser tempat jerapan kation-kation polivalen lain seperti $\mathrm{Ca}^{2+}$ dan $\mathrm{Mg}^{2+}$ serta menjadi pengikat $\mathrm{P}$ dengan kuat. Hale dan Orcutt (1987) menegaskan bahwa sel akan menjadi binukleat bila aluminium memasuki inti sel, selain itu penetrasi aluminium juga mempengaruhi enzim pengatur deposisi polisakarida dinding sel yang menjadikan dinding sel akan menjadi kaku.

\section{Perubahan Derajat Kemasaman Media (pH)} Tanaman Lamtoro (L. leucocephala cv. Tarramba) Tercekam $\mathrm{Al}^{3+}$

Kemasaman $(\mathrm{pH})$ menggambarkan perubahan karakteristik media yang berkaitan dengan status morfofisiologi tanaman. Mekanisme toleransi Al terdiri dari mekanisme eksklusi dan mekanisme toleransi internal sel. Mekanisme eksklusi terdiri dari imobilisasi pada dinding sel, permeabilitas selektif dari membran plasma, eksudasi asam organik pengkelat, eksudasi fosfat, aliran keluar Al dan meningkatnya $\mathrm{pH}$ dalam rizosfer atau apoplas akar. Kemasaman $(\mathrm{pH})$ merupakan salah satu indikator mekanisme toleransi Al model eksklusi yang akan mengakibatkan proses peningkatan atau penurunan $\mathrm{pH}$ di daerah media. Perubahan derajat kemasaman media $(\mathrm{pH})$ disajikan pada Tabel 3 .

Hasil penelitian menunjukkan bahwa status pH media terjadi perubahan pada akhir penelitian dengan pola perubahan yang bervariasi. Perubahan pada kontrol (tanpa penambahan $\mathrm{Al}^{3+}$ ) cenderung menurun diakhir penelitian. Hasil berbeda pada level $\mathrm{Al}^{3+} 100 \mathrm{ppm}$ dan 200 ppm yang cenderung meningkat di akhir penelitian. Penurunan $\mathrm{pH}$ media 
Tabel 3. Perubahan derajat keasaman media $(\mathrm{pH})$ tanaman (L. leucocephala cv. tarramba) berdasarkan level pemberian $\mathrm{Al}^{3+}$

\begin{tabular}{lccc}
\hline \multirow{2}{*}{ pH Media } & \multicolumn{3}{c}{ Level $^{3{ }^{3+}(\mathrm{ppm})^{*}}$} \\
\cline { 2 - 4 } & 0 & 100 & 200 \\
\hline $\mathrm{pH}$ awal & 6,5 & 5,5 & 4,4 \\
$\mathrm{pH}$ akhir & $5,96 \pm 0,17$ & $6,26 \pm 0,16$ & $5,82 \pm 0,22$ \\
$\Delta \mathrm{pH}$ & $-0,54 \pm 0,17 \mathrm{c}$ & $0,76 \pm 0,15 \mathrm{~b}$ & $1,42 \pm 0,22 \mathrm{a}$ \\
\hline
\end{tabular}

Superskrip berbeda pada baris yang sama menunjukkan beda nyata $(P<0.05)$

menjadi asam diduga akibat penyerapan kation (K, $\mathrm{Ca}, \mathrm{Mg}, \mathrm{Na}$ ) oleh tanaman dan kondisi sebaliknya, peningkatan $\mathrm{pH}$ media diakibatkan penyerapan anion $\left(\mathrm{NO}_{3}^{-}, \mathrm{PO}_{4}^{-}\right)$oleh tanaman. Hajardi dan Yahya (1988) menyatakan bahwa perubahan $\mathrm{pH}$ pada daerah rizosfer berhubungan dengan kemampuan tanaman dalam penyerapan $\mathrm{NO}_{3}{ }^{-}$dan $\mathrm{NH}_{4}^{+}$. Indikasi apabila $\mathrm{NO}_{3}^{-}$lebih banyak diserap maka $\mathrm{pH}$ sitosol akan turun yang menyebabkan meningkatnya aktivitas enzim malat untuk merangsang terbentuknya piruvat dari dekarboksilasi malat. Selain itu, dapat mengakibatkan terjadinya reduksi ion hidroksil $\left(\mathrm{OH}^{-}\right)$atau ion bikarbonat $\left(\mathrm{HCO}_{3}^{-}\right)$ke arah sistem perakaran sehingga akan meningkatkan $\mathrm{pH}$ dan akan mengurangi kelarutan aluminium.

\section{SIMPULAN}

Pertambahan tinggi kanopi tanaman menurun seiring meningkatnya level $\mathrm{Al}^{3+}$ dan jumlah kerontokan daun majemuk meningkat seiring meningkatnya level $\mathrm{Al}^{3+}$. Penambahan $\mathrm{Al}^{3+}$ cenderung meningkatkan nilai akhir $\mathrm{pH}$ media dibandingkan nilai $\mathrm{pH}$ diawal perlakuan.

\section{REFERENSI}

Black, C. A. 1967. Soil-Plant Relationships. Ed.2 Wiley. New York.

Hajardi, S. S., dan Yahya, S. 1988. Fisiologi Stress Lingkungan. Bogor (ID): IPB Press.

Hale, G. M., dan Orcutt, D. M. 1987. The Physiology of Plant Under Stress. John Willey and Sons, Inc. New York.

Hidayat, A, dan Mulyani A. 2005. Lahan kering untuk pertanian dalam Teknologi Pengelolaan Lahan Kering Menuju Pertanian Produktif dan Ramah Lingkungan. Bogor (ID): PPPTA Balitbang.

Hoult, E. H., Briant, P. P. 1974. Practice experiments and demonstration dalam: Whiteman P. C., Humpreys, L. R., dan Mounteith, N. H. A Course Manual in Tropical Pasture Science. Australia Vice Chancerllors Committee. Brisbane. 351-352. Marschner, H. 1995. Mineral Nutrition of Higher Plants. Second edition. Acad Press. 889p. Wright PW. 1989. Transportation Enginnering: Planning and Design. Edisi ketiga. United States of America (US): John Stilley.

Yumiarty, H., dan Suradi, K. 2010. Utilization of lamtoro leaf in diet on pet production and the lose of hair rabbit's pelt. Jurnal Ilmu Ternak. 7(1): 7 